\title{
Correction to: Comparison of personality between juveniles and adults in clonal gecko species
}

\author{
Osamu Sakai ${ }^{1}$ (i)
}

Published online: 31 December 2018

(c) The Author(s) 2018

\section{Correction to: Journal of Ethology (2018) 36:221-228 https://doi.org/10.1007/s10164-018-0551-2}

The article Comparison of personality between juveniles and adults in clonal gecko species, written by Osamu Sakai was originally published electronically on the publisher's internet portal (currently SpringerLink) on 8 June, 2018 without open access. With the author(s)' decision to opt for Open Choice the copyright of the article changed on 31 December, 2018 to (C) The Author(s) 2018 and the article is forthwith distributed under the terms of the Creative Commons Attribution 4.0 International License (http://creativecommons .org/licenses/by/4.0/), which permits use, duplication, adaptation, distribution and reproduction in any medium or format, as long as you give appropriate credit to the original author(s) and the source, provide a link to the Creative Commons license and indicate if changes were made.

The original article has been corrected

Open Access This article is distributed under the terms of the Creative Commons Attribution 4.0 International License (http://creativeco mmons.org/licenses/by/4.0/), which permits unrestricted use, distribution, and reproduction in any medium, provided you give appropriate credit to the original author(s) and the source, provide a link to the Creative Commons license, and indicate if changes were made.

The original article can be found online at https://doi.org/10.1007/ s10164-018-0551-2.

Osamu Sakai

osamu-lac@ethol.zool.kyoto-u.ac.jp

1 Department of Zoology, Graduate School of Science, Kyoto University, Kitashirakawa Oiwake, Sakyo, Kyoto 606-8502, Japan 